\title{
PENERAPAN MODEL PEMBELAJARAN KOOPERATIF TIPE EXAMPLES NON EXAMPLES UNTUK MENINGKATKAN AKTIVITAS DAN KEMAMPUAN BERPIKIR KRITIS PESERTA DIDIK SMP NEGERI 3 BATANGHARI
}

\author{
Brigita Ivana Kurniati $^{1}$, H. Jazim Ahmad ${ }^{2}$, Dwi Rahmawati ${ }^{3}$ \\ 1, 2,3 Prodi Pendidikan Matematika Universitas Muhammadiyah Metro \\ Iringmulyo, Kota Metro, Lampung, Indonesia \\ e-mail: ${ }^{3}$ dwirahmawati1083@gmail.com;
}

\begin{abstract}
Abstrak
Penelitian ini bertujuan untuk mengetahui peningkatan aktivitas belajar dan kemampuan berpikir kritis peserta didik pada materi lingkaran melalui penerapan pembelajaran kooperatif tipe Examples Non Examples kelas VIII5 SMP Negeri 3 Batanghari. Jenis penelitian ini adalah penelitian tindakan kelas yang terdiri dari empat tahap meliputi: perencanaan, pelaksanaan, pengamatan, dan refleksi. Subjek penelitian ini adalah peserta didik kelas VIII5 di SMP Negeri 3 Batanghari. Pengumpulan data ini menggunakan instrumen berupa lembar observasi aktivitas belajar dan lembar tes kemampuan berpikir kritis yang terdiri dari 5 soal. Hasil penelitian menunjukkan adanya: 1) Peningkatan aktivitas belajar dalam pembelajaran yang dilakukan. Hal ini dapat dilihat dari peningkatan setiap indikatornya, rata-rata persentase aktivitas belajar per indikator yaitu: a) Memperhatikan penyajian materi dari pendidik, pada pra-survey sebesar $78 \%$, meningkat menjadi $69,23 \%$ pada siklus I, kemudian meningkat menjadi $82 \%$ pada siklus II. b) Mengajukan pertanyaan, pada pra-survey sebesar 9\%, meningkat menjadi 46,17\% pada siklus I, kemudian meningkat menjadi $62,8 \%$ pada siklus II. c) Menjawab pertanyaan, pada pra-survey sebesar $4 \%$, meningkat menjadi $42,33 \%$ pada siklus I, kemudian meningkat menjadi $61,57 \%$ pada siklus II. d) Aktif dalam berdiskusi kelompok, pada pra-survey sebesar 57\%, meningkat menjadi 55,1\% pada siklus I, kemudian meningkat menjadi 65,37\% pada siklus II. e) Mempresentasikan tugas kelompok, pada pra-survey sebesar $22 \%$, meningkat menjadi $42,27 \%$ pada siklus I, kemudian meningkat menjadi $62,8 \%$ pada siklus II. 2) Peningkatan persentase hasil belajar kemampuan berpikir kritis peserta didik dari prasurvey sebesar 30,33\% meningkat menjadi $30,76 \%$ pada siklus I, kemudian meningkat menjadi $65,38 \%$ pada siklus II. Kesimpulan dari penelitian ini adalah bahwa penerapan model pembelajaran kooperatif tipe Examples Non Examples dapat: 1) Meningkatkan aktivitas belajar peserta didik kelas VIII5 SMP Negeri 3 Batanghari Tahun Pelajaran 2018/2019. 2) Meningkatkan hasil belajar yang mengacu pada kemampuan berpikir kritis peserta didik kelas VIII5 SMP Negeri 3 Batanghari
\end{abstract}

Kata Kunci: pembelajaran kooperatif tipe example non example, aktivitas belaajr, kemampuan berpikir kritis

\section{THE APPLICATION OF COOPERATIVE LEARNING TYPE EXAMPLES AND NON EXAMPLES TO IMPROVE CRITICAL THINKING STUDENT OF SMP NEGERI 3 BATANGHARI}

\begin{abstract}
This study aims to determine the increase in learning activities and students' critical thinking abilities in circle material through the application of cooperative learning types Examples and Non Examples in Eight Grade Students of SMP Negeri 3 Batanghari. The research method is classroom action research which consists of four stages including: planning, implementation, observation, and reflection. The subjects of this study were students of class Eight Grade Students of SMP Negeri 3 Batanghari. Data collection uses instruments in the form of learning activity observation sheets and critical thinking ability test sheets consisting of 5 questions. The results of the study indicate the existence of: 1) Increased learning activities in the learning process. This can be seen from the increase in each indicator, the average percentage of learning activities per indicator, namely: a) focus of material presentation from
\end{abstract}


teacher in the pre-survey is $78 \%$. It decreases to $69.23 \%$ in the first cycle, then increasing to $82 \%$ in second cycle. b) Asking questions, in pre-survey at $9 \%$, increased to $46.17 \%$ in first cycle, then increased to $62.8 \%$ in second cycle. c) Answering questions, in pre-survey by $4 \%$, increasing to $42.33 \%$ in first cycle, and then increasing to $61.57 \%$ in second cycle. d) The activity in group discussions, in pre-survey by $57 \%$, increasing to $55.1 \%$ in the first cycle, and then increasing to $65.37 \%$ in cycle II. e) Presenting group assignments, in pre-survey by $22 \%$, increasing to $42.27 \%$ in first cycle, and then increasing to $62.8 \%$ in second cycle. 2) Increasing the percentage of learning outcomes of students' critical thinking skills from pre-survey by $30.33 \%$, increasing to $30.76 \%$ in cycle I, and then increasing to $65.38 \%$ in cycle II. The conclusion of this study is that the application of the cooperative learning model type Examples Non Examples can: 1) Increase the learning activities of Eight Grades students of SMP Negeri 3 Batanghari 2018/2019 Academic Year. 2) Learning outcomes that refer to the critical thinking skills of Eight Grade Students of SMP Negeri 3 Batanghari ware improve.

Keywords: cooperative learning type example non example, learning activities, critical thinking skills

\section{Pendahuluan}

Pelajaran Matematika merupakan salah satu bidang studi yang sistematis, cermat, konsisten, dan logis. Selain itu, pelajaran Matematika merupakan mata pelajaran yang diajarkan di semua tingkat pendidikan baik tingkat SD, SMP, SMA hingga berpendidikan tinggi dan memiliki peran yang sangat penting dalam penguasaan ilmu pengetahuan. Namun kebanyakan peserta didik merasa kesulitan dalam mempelajari Matematika. Kecenderungan pelajaran Matematika dianggap sulit, terkadang menjadi pemicu malasnya peserta didik untuk memperhatikan materi dan kurangnya aktivitas dalam pembelajaran sehingga menyebabkan peserta didik mengalami kesulitan dalam belajar Matematika. Dengan begitu perlu dilakukan suatu upaya untuk memudahkan peserta didik dalam memahami konsep Matematika yaitu pendidik, dimana peran pendidik sangat penting sebagai tenaga pendidik untuk membantu mengembangkan pemikiran peserta didik dalam menyelesaikan masalah pembelajaran di dalam kelas secara bijaksana dan pendidik harus lebih kreatif dalam mengkaji materi serta mengaktifkan suasana pembelajaran dikelas agar peserta didik berpartisipasi aktif sebagai subyek belajar bukannya menjadi objek belajar, dengan begitu peserta didik lebih mudah dalam memahami materi yang disampaikan dan diharapkan dapat mencapai hasil belajar yang maksimal.

Pra-survei di SMP Negeri 3 Batanghari pada tanggal 21 Maret 2018 menunjukan aktivitas belajar peserta didik kelas VIII5 SMP Negeri 3 Batanghari Tahun Pelajaran 2017/2018 masih tergolong pasif dengan indikator (1) Memperhatikan penyajian materi dari pendidik $78 \%$; (2) Mengajukan pertanyaan 9\%; (3) Menjawab pertanyaan 4\%; (4) Aktif dalam berdiskusi kelompok 57\%; (5) Mempresentasikan tugas kelompok 22\%. Padahal, aktivitas belajar matematika dapat dikatakan berperan aktif apabila setiap indikator aktivitas belajar mencapai target persentase $\geq 61 \%$ dengan kategori aktif (Aminoto dan Pathoni, 2014:23). Siswa yang tuntas untuk ujian tengah semester hanya 4\% (nilai $\geq 76$ ) dan 96\% tidak tuntas. Sedangkan untuk kemampuan berpikir kritis, kemampuan menginterpretasi $22 \%$, kemampuan mengevaluasi $39 \%$ dan kemampuan menginferensi $30 \%$.

Rendahnya kemampuan berpikir kritis peserta didik kemungkinan besar dikarenakan kurang tepatnya model pembelajaran yang digunakan dalam proses pembelajaran di kelas. Pemilihan model pembelajaran yang tepat merupakan salah satu solusi untuk meningkatkan kemampuan berpikir kritis peserta didik dan memaksimalkan proses pembelajaran di kelas. Dibutuhkan suatu penerapan model pembelajaran yang mendorong kemampuan peserta didik untuk meningkatkan aktivitas dan hasil belajar yang mengacu pada kemampuan berpikir kritis. Salah satu model pembelajaran yang dapat digunakan adalah model pembelajaran kooperatif tipe examples non examples.

Model pembelajaran kooperatif tipe examples non examples adalah model pembelajaran alternatif yang menggunakan contoh dalam kehidupan sehari-hari dan bukan contoh dalam kehidupan sehari-hari melalui media gambar berkaitan dengan materi yang akan disampaikan. Melalui model ini, peserta didik diberi kesempatan untuk menganalisa dan mendiskusikan contoh gambar yang disusun dan dirancang, kemudian dipresentasikan di depan kelas. Penggunaan gambar disusun dan dirancang agar anak dapat menganalisis gambar tersebut mengenai apa yang ada didalamnya. Selain itu, model pembelajaran tipe examples non examples melibatkan peserta didik secara penuh pada proses pembelajaran, sehingga dari awal persiapan pembelajaran hingga evaluasi pembelajaran dapat 
memberikan pembelajaran yang bermakna pada peserta didik.

Berdasarkan uraian permasalahan di atas, maka perlu melakukan penelitian lebih lanjut terkait "Penerapan Model Pembelajaran Kooperatif Tipe Examples Non Examples Untuk Meningkatkan Aktivitas dan Hasil Belajar Peserta didik SMP Negeri 3 Batanghari.

\section{Metode Penelitian}

Penelitian ini adalah Penelitian Tindakan Kelas (PTK) yang bertujuan untuk meningkatkan aktivitas dan kemampuan berpikir kritis peserta didik kelas VIII5 SMP Negeri 3 Batanghari. PTK terdiri dari perencanaan tindakan, pelaksanaan tindakan, pengamatan, dan refleksi yang merupakan langkah-langkah berurutan dalam satu siklus. Instrumen yang digunakan adalah lembar observasi aktivitas siswa dengan indikator (1) memperhatikan penyajian materi, (2) mengajukan pertanyaan, (3) menjawab pertanyaan, (4) aktif dalam berdiskusi kelompok, dan (5) mempresentasikan tugas kelompok; dan tes kemampuan berpikir kritis dengan indikator (1) Menginterpretasi: memahami masalah yang ditunjukkan dengan menulis diketahui maupun yang ditanyakan soal yag tepat; (2) Mengevaluasi: menggunakan strategi yang tepat dalam penyelesaian soal dengan benar dan lengkap dalam melakukan perhitungan; (3) Menginferensi: membuat kesimpulan dengan tepat. Sebelum digunakan, kedua instrumen ini telah diuji validitas isi oleh ahli dan uji reliabilitas.

Persentase aktivitas pada pembelajaran dihitung dengan rumus:

$$
A \%=\frac{\sum N A}{\sum N} \times 100 \%
$$

sedangkan data hasil belajar yang mengacu pada kemampuan berpikir kritis dihitung dengan menggunakan rumus:

$$
K a=\frac{\sum N a}{\sum N} \times 100 \%
$$

Keterangan:

$A \%=$ Persentase aktivitas belajar peserta didik

$K a=$ Tingkat ketuntasan belajar

$\sum N a=$ Jumlah hasil belajar peserta didik yang mendapat skor $\geq 61$

$\sum N=$ Jumlah peserta didik

Indikator keberhasilan yang diharapkan dalam Penelitian Tindakan Kelas (PTK) ini adalah: a. Aktivitas Belajar Matematika peserta didik dapat meningkat dengan kategori persentase aktif yang meningkat di setiap siklusnya. Menurut Kusuma dan Aisya (2012:56) standar minimal yang ditentukan yaitu sekurang-kurangnya $75 \%$ peserta didik terlibat secara aktif, baik fisik, mental, maupun sosial dalam proses pembelajaran". Selanjutnya Aminoto dan Pathoni (2014:23) menyatakan bahwa kriteria indikator aktivitas belajar peserta didik disajikan pada tabel 1 berikut ini:

Tabel 1. Kategori Aktivitas Belajar Peserta Didik

\begin{tabular}{lll}
\hline $0-20$ & $=$ & Tidak Aktif \\
$21-40$ & $=$ & Kurang Aktif \\
$41-60$ & $=$ & Cukup Aktif \\
$61-80$ & $=$ & Aktif \\
$81-100$ & $=$ & Sangat Aktif \\
\hline
\end{tabular}

Target rata-rata peningkatan aktivitas peserta didik yang ingin dicapai dalam penelitian yaitu $\geq 61$ dikategorikan aktif.

b. Nilai Hasil Belajar

Nilai hasil belajar peserta didik yang mengacu pada kemampuan berpikir dapat meningkat dengan kategori persentase yang meningkat di setiap siklusnya dan memenuhi Kriteria Ketentusan Minimal (KKM) yaitu menjadi $\geq$ 61. Menurut Syahbana (2012:23) menyatakan bahwa "data hasil tes peserta didik dianalisis untuk menentukan rata-rata nilai akhir dan kemudian dikonversikan ke dalam data kualitatif untuk menentukan kategori tingkat kemampuan berpikir kritis matematis peserta didik". Persentase tingkat kemampuan berpikir kritis matematis peserta didik tersebut dapat dilihat pada tabel 2 berikut:

Tabel 2. Kategori tingkat kemampuan peserta didik memahami soal-soal kemampuan berpikir kritis matematis

\begin{tabular}{c|c}
\hline Nilai Siswa & Kategori \\
\hline $81-100$ & Sangat Baik \\
$61-80,999$ & Baik \\
$41-60,999$ & Cukup \\
$21-40,999$ & Kurang \\
$0-20,999$ & Sangat Kurang \\
\hline
\end{tabular}

Target rata-rata peningkatan hasil belajar yang mengacu pada kemampuan berpikir kritis peserta didik yang ingin dicapai dalam penelitian yaitu $\geq 61$ dikategorikan baik 


\section{Hasil dan Pembahasan}

\subsection{Siklus 1}

Berdasarkan hasil penelitian, diperoleh data tentang aktivitas peserta didik pada siklus 1 sebagai berikut:

Tabel 3. Data Aktivitas Peserta Didik Pada Siklus I

\begin{tabular}{|c|c|c|c|c|c|c|c|}
\hline \multirow{3}{*}{ No } & \multirow{3}{*}{ Indikator } & \multicolumn{5}{|c|}{ Siklus I } & \multirow{3}{*}{ Ket } \\
\hline & & \multicolumn{3}{|c|}{ Pertemuan } & \multirow{2}{*}{$\begin{array}{c}\text { Rata-rata } \\
(\%)\end{array}$} & \multirow{2}{*}{ Target } & \\
\hline & & 1 & 2 & 3 & & & \\
\hline 1 & $\begin{array}{l}\text { Memperhatikan } \\
\text { penyajian materi dari } \\
\text { pendidik }\end{array}$ & $57,7 \%$ & $65,4 \%$ & $84,6 \%$ & $69,23 \%$ & \multirow{5}{*}{$\geq 61 \%$} & + \\
\hline 2 & $\begin{array}{l}\text { Mengajukan } \\
\text { pertanyaan }\end{array}$ & $38,5 \%$ & $50 \%$ & $50 \%$ & $46,17 \%$ & & - \\
\hline 3 & Menjawab pertanyaan & $38,5 \%$ & $38,5 \%$ & $50 \%$ & $42,33 \%$ & & - \\
\hline 4 & $\begin{array}{l}\text { Aktif dalam berdiskusi } \\
\text { kelompok }\end{array}$ & $53,8 \%$ & $53,8 \%$ & $57,7 \%$ & $55,1 \%$ & & - \\
\hline 5 & $\begin{array}{l}\text { Mempresentasikan } \\
\text { tugas kelompok }\end{array}$ & $38,5 \%$ & $38,5 \%$ & $50 \%$ & $42,33 \%$ & & - \\
\hline
\end{tabular}

Keterangan:

+ : memenuhi target PTK

- : belum memenuhi target PTK

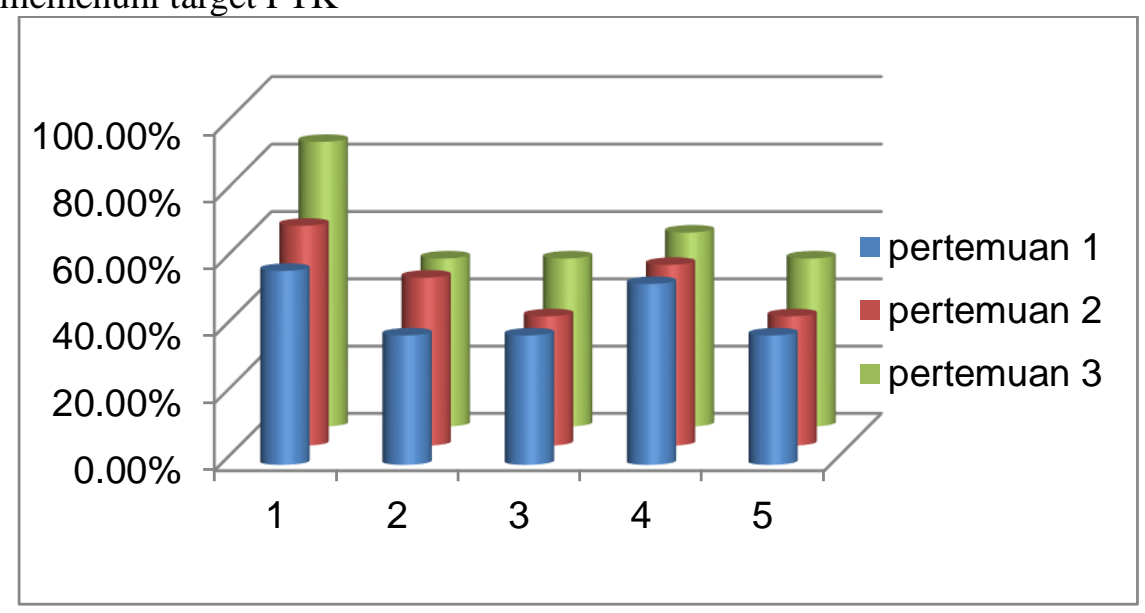

Gambar 1. Diagram aktivitas peserta

Hasil Belajar Peserta Didik yang Mengacu Pada Kemampuan Berpikir Kritis Siklus I

Data hasil belajar ditunjukkan oleh nilai hasil tes kemampuan berpikir kritis siklus I dan mengacu pada tiga indikator yaitu menginterpretasi, mengevaluasi, dan menginferensi. Tes dikerjakan secara individual.

Tabel 4. Hasil Belajar Kemampuan Berpikir Kritis Peserta Didik Siklus I

\begin{tabular}{|c|c|c|}
\hline No & Perolehan & $\begin{array}{l}\text { Hasil } \\
\text { Tes }\end{array}$ \\
\hline 1 & $\begin{array}{llll}\text { Jumlah Peserta } & \text { Didik yang } \\
\text { Tuntas } & & & \end{array}$ & 8 \\
\hline 2 & $\begin{array}{l}\text { Jumlah Peserta Didik yang } \\
\text { Tidak Tuntas }\end{array}$ & 18 \\
\hline 3 & Skor Tertinggi & 97 \\
\hline 4 & Skor Terendah & 0,7 \\
\hline 5 & Persentase Ketuntasan & $30,76 \%$ \\
\hline
\end{tabular}

Diagram Hasil Belajar Kemampuan Berpikir Kritis Peserta didik Siklus I ditunjukkan oleh Gambar 2

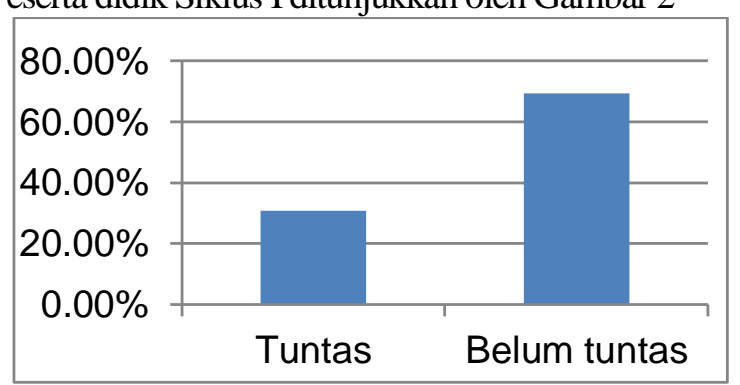

Gambar 2. Diagram hasil belajar kemampuan berpikir kritis peserta didik siklus I

Berdasarkan hasil belajar kemampuan berpikir kritis peserta didik siklus I dengan tiga kali pertemuan pada materi lingkaran melalui penerapan model pembelajaran kooperatif tipe examples non examples, terlihat bahwa persentase ketuntasan sebesar 30,76\%. Dalam siklus I, hasil belajar peserta didik belum semuanya tuntas, ketuntasan hasil belajar kemampuan berpikir kritis target yang ingin dicapai yaitu $\geq 61 \%$. 
Banyaknya peserta didik yang belum tuntas disebabkan karena adanya proses pembelajaran yang kurang maksimal, sehingga perlu dilanjutkan penelitian pada siklus II agar mencapai target yang diharapkan.

Hasil tes akhir siklus 1 menunjukkan bahwa proses pembelajaran dengan model pembelajaran kooperatif tipe examples non examples dapat meningkatkan aktivitas dan hasil belajar kemampuan berpikir kritis peserta didik, namun peningkatannya belum mencapai apa yang diharapkan. Hasil refleksi aktivitas selama pembelajaran adalah: (1) Peserta didik belum sepenuhnya memperhatikan informasi yang disampaikan oleh pendidik; (2) Motivasi peserta didik dalam bekerja sama kelompok masih kurang, (3) ada peserta didik yang belum mengerti untuk menyelesaikan soal; (4) Masih rendahnya kemauan dan keberanian peserta didik untuk bertanya pada pendidik; (5) Peserta didik tidak percaya diri untuk menyampaikan hasil diskusi kelompok.

Berdasarkan hasil refleksi pada siklus I, tindakan yang akan dilakukan untuk memperbaiki pada siklus II, sebagai berikut: (1) Memberikan motivasi tentang pentingnya memperhatikan penjelasan guru, bertanya dan percaya diri; (2) Memberikan motivasi peserta didik untuk aktif bekerja sama dalam kelompok; (3) Memberikan cara mudah untuk menyelesaikan soal dengan model pembelajaran tipe examples non examples melalui contoh gambar dalam kehidupan sehari-hari.

Keterangan pada gambar harus terlihat di bawah gambar. Acuan yang menggunakan gambar, tabel, teorema maupun lemma, harus diawali dengan huruf capital tanpa tanda titik pemisah, contoh, Gambar 1 dan Tabel 1 merupakan ilustrasi dari Teorema 1. Semua keterangan yang menyertainya ditulis dengan huruf besar di awal saja.

\subsection{Siklus 1I}

Pada tahap perencanaan, peneliti (1) menyusun silabus pembelajaran dan RPP; (2) membuat LKPD dan kisi-kisi serta soal tes dan kunci jawabannya, (3) membuat lembar observasi aktivitas belajar. Proses pembelajaran siklus II dilaksanakan sebanyak 4 kali pertemuan dan hasil yang diperoleh adalah sebagai berikut:

Tabel 5. Data Aktivitas Peserta Didik Pada Siklus II

\begin{tabular}{|c|c|c|c|c|c|c|c|}
\hline \multirow{3}{*}{ No } & \multirow{3}{*}{ Indikator } & \multicolumn{5}{|c|}{ Siklus II } & \multirow{3}{*}{ Ket } \\
\hline & & \multicolumn{3}{|c|}{ Pertemuan } & \multirow{2}{*}{$\begin{array}{c}\text { Rata-rata } \\
(\%)\end{array}$} & \multirow{2}{*}{ Target } & \\
\hline & & 1 & 2 & 3 & & & \\
\hline 1 & $\begin{array}{l}\text { Memperhatikan } \\
\text { penyajian materi dari } \\
\text { pendidik }\end{array}$ & $65,3 \%$ & $84,6 \%$ & $96,1 \%$ & $82 \%$ & \multirow{5}{*}{$\geq 61 \%$} & + \\
\hline 2 & $\begin{array}{l}\text { Mengajukan } \\
\text { pertanyaan }\end{array}$ & $53,8 \%$ & $65,4 \%$ & $69,2 \%$ & $62,8 \%$ & & + \\
\hline 3 & Menjawab pertanyaan & $38,5 \%$ & $65,4 \%$ & $80,8 \%$ & $61,57 \%$ & & + \\
\hline 4 & $\begin{array}{l}\text { Aktif dalam berdiskusi } \\
\text { kelompok }\end{array}$ & $61,5 \%$ & $76,9 \%$ & $57,7 \%$ & $65,37 \%$ & & + \\
\hline 5 & $\begin{array}{l}\text { Mempresentasikan } \\
\text { tugas kelompok }\end{array}$ & $57,7 \%$ & $34,6 \%$ & $96,1 \%$ & $62,8 \%$ & & + \\
\hline
\end{tabular}

Keterangan:

$+:$ memenuhi target PTK

- : belum memenuhi target PTK

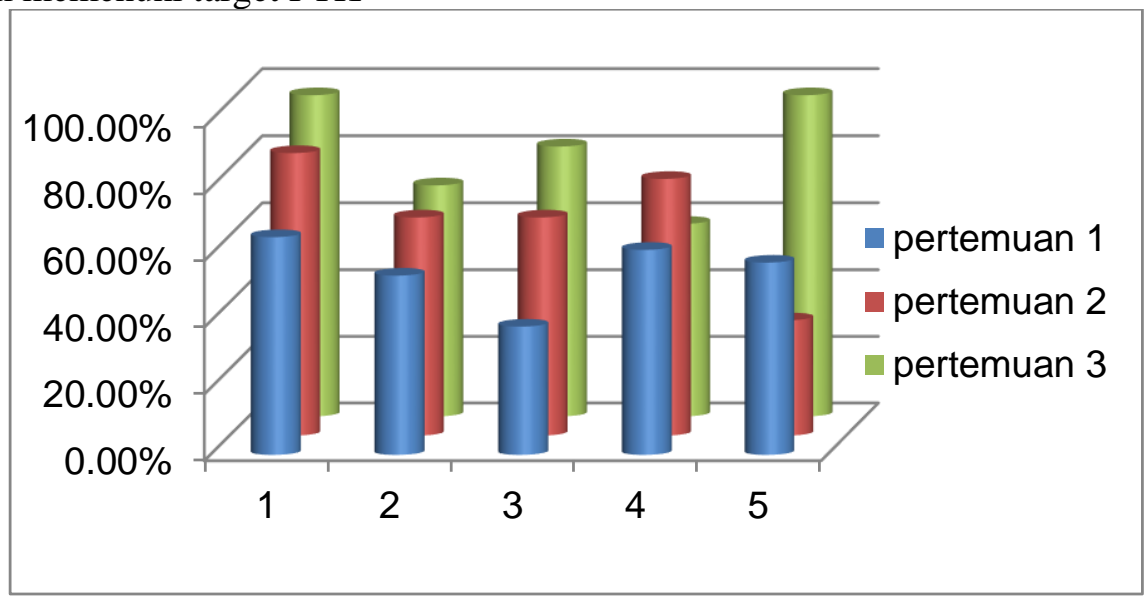

Gambar 3. Diagram aktivitas peserta siklus II 
Hasil Belajar Peserta Didik yang Mengacu Pada Kemampuan Berpikir Kritis Siklus II

Data hasil belajar ditunjukkan oleh nilai hasil tes kemampuan berpikir kritis siklus I. Soal tes kemampuan berpikir kritis yang mengacu pada tiga indikator yaitu menginterpretasi, mengevaluasi, dan menginferensi. Tes dikerjakan secara individual

Tabel 6. Hasil Belajar Kemampuan Berpikir Kritis Peserta Didik Siklus II

\begin{tabular}{c|lll|c}
\hline \multirow{2}{*}{ No } & \multicolumn{3}{|c|}{ Perolehan } & Hasil \\
Tes \\
\hline 1 & Jumlah Peserta Didik yang & 17 \\
& $\begin{array}{l}\text { Tuntas } \\
2\end{array}$ & Jumlah Peserta Didik yang & 9 \\
& Tidak Tuntas & & & \\
3 & Skor Tertinggi & & 100 \\
4 & Skor Terendah & 2,5 \\
5 & Persentase Ketuntasan & $65,38 \%$ \\
\hline
\end{tabular}

Diagram Hasil Belajar Kemampuan Berpikir Kritis Peserta didik Siklus II ditunjukkan oleh Gambar 4

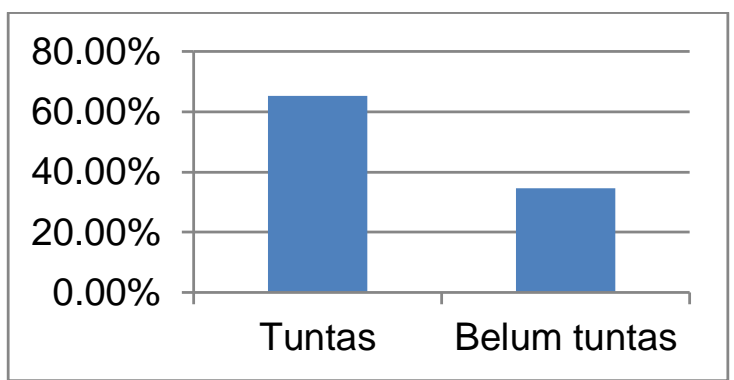

Gambar 4. Diagram hasil belajar kemampuan berpikir kritis peserta didik siklus II

\subsection{Pembahasan}

Berdasarkan data aktivitas belajar peserta didik yang diamati selama proses pembelajaran dengan menggunakan model pembelajaran tipe examples non examples siklus I dan siklus II telah mengalami peningkatan dari setiap siklusnya, dan setiap indikator telah mencapai target yang diharapkan.

Tabel 7. Data Aktivitas Belajar Peserta Didik Siklus I dan Siklus II

\begin{tabular}{l|l|c|c|c|c}
\hline \multirow{2}{*}{ No } & \multicolumn{1}{|c|}{ Aktivitas Yang Diamati } & Target & \multicolumn{2}{|c}{ Siklus } & \multirow{2}{*}{ Ket } \\
\cline { 4 - 5 } & & PTK & I & II & \\
\hline 1 & Memperhatikan penyajian materi dari & & $69,23 \%$ & $82 \%$ & + \\
& pendidik & & $46,17 \%$ & $62,8 \%$ & + \\
2 & Mengajukan pertanyaan & $\geq 61 \%$ & $42,33 \%$ & $61,57 \%$ & + \\
3 & Menjawab pertanyaan & & $55,1 \%$ & $65,37 \%$ & + \\
4 & Aktif dalam berdiskusi kelompok & & $42,27 \%$ & $62,8 \%$ & + \\
5 & Mempresentasikan tugas kelompok & & \multicolumn{3}{|}{} \\
\hline
\end{tabular}

Keterangan:

$+:$ memenuhi target PTK

- : belum memenuhi target PTK

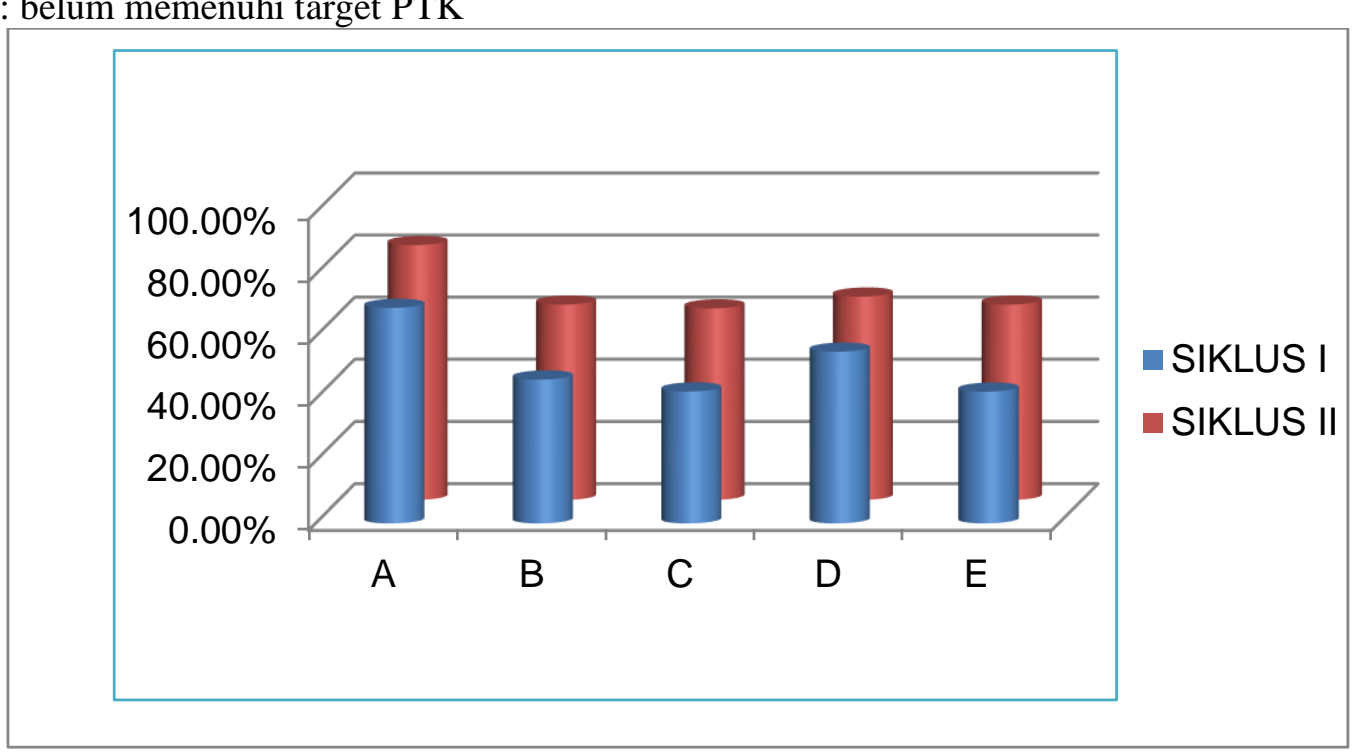

Gambar 5. Diagram aktivitas peserta siklus I dan siklus II

Pembelajaran model kooperatif tipe Examples

Non Examples menunjukkan bahwa peingkatan aktivitas belajar peserta didik menjadi lebih baik yaitu peserta didik lebih antusias dalam mengikuti 
pembelajaran. Hal ini sependapat dengan Habibah (2016:58) yang menyatakan bahwa "pada pembelajaran dengan menerapkan model pembelajaran examples non examples secara tidak langsung peserta didik menjadi lebih aktif berdiskusi, berani mengemukakan pendapat atau gagasannya sendiri, dapat belajar dari pengamatan sendiri". Selain itu model pembelajaran tipe examples non examples ini memiliki kelebihan, salah satu kelebihannya yaitu peserta didik diberi kesempatan untuk mengemukakan pendapatnya mengenai hasil analisa gambar pada materi lingkaran. Hal ini sependapat dengan Yanuarto (2016:77) "pembelajaran examples non examples memberi kesempatan yang luas kepada setiap anggota kelompok untuk saling memberikan informasi dan saling membelajarkan".

Peningkatan aktivitas belajar peserta didik meningkat dikarenakan adanya model pembelajaran tipe examples non examples yang membuat peserta didik terlibat secara langsung dalam proses belajar di kelas. Hal ini sependapat dengan Saleha, dkk (2016:47) bahwa "model pembelajaran example non example melibatkan keaktifan dan kerja sama siswa dalam pembelajaran yaitu peserta didik melakukan diskusi kelompok dan menyampaikan hasil diskusinya". Melalui berbagai aktivitas belajar yang sesuai dengan pembelajaran, maka peserta didik lebih mudah dan mampu untuk mengingat, memahami, dan mengaplikasikan materi yang telah diajarkan.

Meningkatnya hasil belajar yang mengacu pada kemampuan berpikir kritis dikarenakan adanya penerapan model pembelajaran yang mendorong peserta didik mampu untuk mengolah atau memproses hasil pemikirannya dengan mengetahui apa yang harus dikerjakan dan bagaimana caranya. Salah satu model pembelajaran yang dapat meningkatkan hasil belajar yang mengacu pada kemampuan berpikir kritis yaitu model pembelajaran tipe examples non examples. Model pembelajaran tipe examples non examples ini memiliki peranan penting yaitu peserta didik berpikir kritis terhadap suatu gambar, sehingga belajar dan berpikir yang dilakukan peserta didik menjadi lebih efektif dan efisien. Hal ini sependapat dengan Wulandari dan Leonard (2015:109) menyatakan bahwa "metode pembelajaran example non example dapat membantu dalam berpikir kritis dan dapat menyelesaikan permasalahan yang dihadapi. Peserta didik diarahkan untuk mengidentifikasi masalah, mencari alternatif pemecahan masalah, dan menemukan cara pemecahan masalah yang paling efektif, serta melakukan tindak lanjut". Model pembelajaran tipe examples non examples ini merupakan tipe model yang menggunakan media gambar dalam penyampaian materi pembelajaran yang bertujuan mendorong peserta didik untuk belajar berpikir kritis dalam memecahkan permasalahan yang terdapat pada contoh gambar yang disajikan. Dengan berpikir kritis dalam proses pembelajaran, peserta didik diharapkan mampu memiliki kemampuan berpikir lebih baik lagi dalam menghadapi masalah khususnya permasalahan pada pelajaran matematika. Hal ini sependapat dengan Setiawan dan Royani (2013:1) "peserta didik memerlukan kemampuan berpikir kritis yang tinggi karena kemampuan berpikir kritis matematika berperan penting dalam penyelesaian suatu permasalahan mengenai pelajaran matematika". Sehingga hal ini dapat mempengaruhi hasil belajar peserta didik, dengan ketercapaian berpikir kritis dalam menganalisa gambar pada materi lingkaran, maka peserta didik akan lebih paham materi yang disampaikan dan tujuan pembelajaran yang diinginkan akan tercapai. Peningkatan kemampuan berpikir kritis peserta didik juga diperkuat dengan pemahaman yang mendalam mengenai konsep suatu materi sehingga dapat menjamin bahwa pemikiran peserta didik terhadap suatu konsep tersebut adalah benar, selain itu melalui penerapan model pembelajaran tipe examples non examples peserta didik dapat memahami dan lebih mudah mengingat materi yang dipelajarinya.

\section{Kesimpulan}

Berdasarkan hasil Penelitian Tindakan Kelas (PTK) dan pembahasan yang telah dikemukakan maka dapat diambil kesimpulan, sebagai berikut:

a. Penerapan model pembelajaran kooperatif tipe examples non examples dapat meningkatkan aktivitas belajar Matematika peserta didik kelas VIII5 SMP Negeri 3 Batanghari Tahun Pelajaran 2018/2019. Berdasarkan rata-rata aktivitas setiap indikatornya mengalami peningkatan, berikut penjelasannya:

i. Memperhatikan penyajian materi dari pendidik pada siklus I sebesar $69,23 \%$ dan pada siklus II meningkat sebesar $82 \%$. Hal ini menunjukkan bahwa aktivitas ini dapat dikatakan meningkat dan memenuhi target.

ii. Mengajukan pertanyaan pada siklus I sebesar $46,17 \%$, pada siklus I indikator ini belum mencapai target yang diharapkan, setelah adanya perbaikan pada siklus II meningkat sebesar $62,8 \%$. Hal ini menunjukkan bahwa aktivitas ini dapat dikatakan meningkat dan memenuhi target.

iii. Menjawab pertanyaan pada siklus I sebesar $42,33 \%$ sedangkan pada siklus II meningkat sebesar $61,57 \%$. Hal ini menunjukkan bahwa aktivitas ini dapat 
dikatakan meningkat dan memenuhi target.

iv. Aktif dalam berdiskusi kelompok pada siklus I sebesar 55,1\% dan meningkat pada siklus II yaitu sebesar $65,37 \%$. Hal ini menunjukkan bahwa aktivitas ini dapat dikatakan meningkat dan memenuhi target.

v. Mempresentasikan tugas kelompok pada siklus I sebesar 42,27\%, kemudian meningkat pada siklus II sebesar $62,8 \%$. Hal ini menunjukkan bahwa aktivitas ini dapat dikatakan meningkat dan memenuhi target.

b. Penerapan model pembelajaran kooperatif tipe examples non examples dapat meningkatkan hasil belajar yang mengacu pada kemampuan berpikir kritis Matematika peserta didik kelas VIII5 SMP Negeri 3 Batanghari Tahun Pelajaran 2018/2019”. Meningkatnya hasil belajar kemampuan berpikir kritis peserta didik dapat dilihat dari data persentase pada siklus I sebesar 30,76\% dan pada siklus II persentase hasil belajar kemampuan berpikir kritis peserta didik meningkat sebesar $34,62 \%$ dan persentasenya menjadi $65,38 \%$ pada siklus II.

\section{Daftar Pustaka}

Aminoto, Tugiyo dan Pathoni, Hairul. 2014. Penerapan Media E-Learning Berbasis Schoology Untuk Meningkatkan Aktivitas dan Hasil Belajar Materi Usaha dan Energi Di Kelas XI SMA N 10 Kota Jambi. Jurnal Sainmatika, Vol 8 No 1 2014

Habibah, Syarifah. 2016. Penggunaan Model Pembelajaran Examples Non Examples Terhadap Ketuntasan Hasil Belajar Siswa Pada Materi Tokoh-Tokoh Pergerakan Nasional Kelas V Sdn 70 Banda Aceh. Jurnal Pesona Dasar, Vol. 3, No. 4, Oktober 2016.

Kusuma, Febrian Widya dan Aisya, Mimin Nir. 2012. Implementasi Model Pembelajaran Kooperatif Tipe Think Pair Share Untuk Meningkatkan Aktivitas Belajar Akutansi Siswa Kelas XI IPS 1 SMA Negeri 2 Wonosari. Jurnal Pendidikan Akutansi Indonesia, Vol. X No. 2 Tahun 2012.

Saleha, Wa Ode, dkk. 2016. Penerapan Model Pembelajaran Example Non Example Untuk Meningkatkan Aktivitas Dan Pemahaman Konsep Siswa Kelas Vii Smp Negeri 4 Parigi Pada Materi Klasifikasi Makhluk Hidup. Jurnal Ampibi, Volume 1, Nomor 1, Mei 2016.

Setiawan, Joko dan Royani. 2013. Kemampuan Berpikir Kritis siswa Dalam Pembelajaran Bangun Sisi Datar Dengan Metode Inkuiri. EduMat, Volume 1, Nomor 1, Oktober 2013.
Syahbana, Ali. 2012. Pengembangan Perangkat Pembelajaran Berbasis Konstektual Untuk Mengukur Kemampuan Berpikir Kritis Matematis Siswa SMP. Edumatica, Volume 02 Nomor 02, Oktober 2012.

Wulandari, Fitri dan Leonard. 2015. Pengaruh Metode Pembelajaran Example Non Example Terhadap Hasil Belajar Matematika Siswa. Seminar Nasional Pendidikan Matematika. Universitas Indraprasta PGRI

Yanuarto, Wanda Nugroho. 2016. Example and NonExample Pada Pembelajaran Matematika. Edumatica, Volume 06 Nomor 01 April 2016. 